\title{
Influence of climate variability on water partitioning and effective energy and mass transfer in a semi-arid critical zone
}

\author{
Xavier Zapata-Rios ${ }^{1, a}$, Paul D. Brooks ${ }^{2,1}$, Peter A. Troch ${ }^{1}$, Jennifer McIntosh $^{1}$, and Craig Rasmussen ${ }^{3}$ \\ ${ }^{1}$ Department of Hydrology and Water Resources, The University of Arizona, Tucson, Arizona, USA \\ ${ }^{2}$ Department of Geology and Geophysics, University of Utah, Salt Lake City, Utah, USA \\ ${ }^{3}$ Soil, Water and Environmental Science, The University of Arizona, Tucson, Arizona, USA \\ ${ }^{\text {a}}$ Facultad de Ingeniería en Ciencias Agropecuarias y Ambientales, Universidad Técnica del Norte, Ibarra, Ecuador \\ Correspondence to: Xavier Zapata-Rios (xavierzapatarios@gmail.com)
}

Received: 25 June 2015 - Published in Hydrol. Earth Syst. Sci. Discuss.: 17 August 2015

Revised: 3 February 2016 - Accepted: 19 February 2016 - Published: 15 March 2016

\begin{abstract}
The critical zone (CZ) is the heterogeneous, nearsurface layer of the planet that regulates life-sustaining resources. Previous research has demonstrated that a quantification of the influxes of effective energy and mass transfer (EEMT) to the CZ can predict its structure and function. In this study, we quantify how climate variability in the last 3 decades (1984-2012) has affected water availability and the temporal trends in EEMT. This study takes place in the $1200 \mathrm{~km}^{2}$ upper Jemez River basin in northern New Mexico. The analysis of climate, water availability, and EEMT was based on records from two highelevation SNOTEL stations, PRISM data, catchment-scale discharge, and satellite-derived net primary productivity (MODIS). Results from this study indicated a decreasing trend in water availability, a reduction in forest productivity $\left(4 \mathrm{~g} \mathrm{C} \mathrm{m}^{-2}\right.$ per $10 \mathrm{~mm}$ of reduction in precipitation), and decreasing EEMT $\left(1.2-1.3 \mathrm{MJ} \mathrm{m}^{2} \mathrm{decade}^{-1}\right)$. Although we do not know the timescales of $\mathrm{CZ}$ change, these results suggest an upward migration of CZ/ecosystem structure on the order of $100 \mathrm{~m} \mathrm{decade}^{-1}$, and that decadal-scale differences in EEMT are similar to the differences between convergent/hydrologically subsidized and planar/divergent landscapes, which have been shown to be very different in vegetation and $\mathrm{CZ}$ structure.
\end{abstract}

\section{Introduction}

The critical zone $(\mathrm{CZ})$ is the surficial layer of the planet that extends from the top of the vegetation canopy to the base of aquifers (Chorover et al., 2011; Brandley et al., 2007). Within its boundaries, complex interactions between air, water, biota, organic matter, soils, and rocks take place that are critical for sustaining life on Earth (Brandley et al., 2007). The CZ has been conceptualized and studied as a weathering engine or reactor where interacting chemical, physical, and biological processes drive weathering reactions (Anderson et al., 2007; Chorover et al., 2011). Over long timescales, the $\mathrm{CZ}$ has evolved in response to climatic and tectonic forces and has been recently influenced by human activities (Steffen et al., 2007). Understanding how climate and land use changes affect $\mathrm{CZ}$ structure and related processes has become a priority for the scientific community due to the implications it may have on the functioning of life-supporting resources. It has been hypothesized by the researchers from the Jemez River basin (JRB) - Santa Catalina Mountains (SCM) critical zone observatory (CZO) (http://criticalzone. org/catalina-jemez/) that a quantification of the inputs of the effective energy and mass transfer (EEMT) to the CZ can provide insight about its structure and function (Chorover et al., 2011). CZ areas that receive greater EEMT influxes have been shown to have greater structural organization as well as more dissipative product removal (Rasmussen et al., 2011; Zapata-Rios et al., 2015a). The opposite has been observed in regions with less EEMT. 
EEMT is a variable that quantifies energy and mass transfer to the CZ (Rasmussen et al., 2011). EEMT integrates within a single variable the energy and mass associated with water that percolates into the $\mathrm{CZ}\left(E_{\mathrm{ppt}}\right)$, and reduced carbon compounds resulting from primary production $\left(E_{\mathrm{bio}}\right)$ (Rasmussen et al., 2011). It has been demonstrated that other possible energy fluxes to the $\mathrm{CZ}$, such as potential energy from transport of sediments, geochemical potential of chemical weathering, external inputs of dust, heat exchange between soil and atmosphere, and other sources of energy coming from anthropogenic sources, are orders of magnitude smaller (Phillips, 2009; Smil, 1991; Rasmussen et al., 2011; Rasmussen, 2012). Therefore the two dominant terms embodied in EEMT are $E_{\text {ppt }}$ and $E_{\text {bio, }}$, and only the energy associated with water and carbon is considered in the EEMT quantification. Energy from both water and net primary productivity is essential for $\mathrm{CZ}$ processes altering soil genesis, mineral dissolution, solute chemistry, and weathering rates (among others) (Birkeland, 1974; Neilson, 2003).

Previous research has shown that EEMT can become a tool to predict regolith depth, rate of soil production, and soil properties (Rasmussen et al., 2005, 2011; Pelletier and Rasmussen, 2009a, b; Rasmussen and Tabor, 2007). For instance, strong correlations were found between EEMT, soil carbon, and clay content in soils on igneous parent materials from California and Oregon (Rasmussen et al., 2005). Furthermore, transfer functions were successfully determined between EEMT and pedogenic indices, including pedon depth, clay content, and chemical indices of soil alteration along an environmental gradient on residual igneous parent material (Rasmussen and Tabor, 2007). EEMT has also been incorporated in geomorphic and pedogenic models on granitic rocks to describe landscape attributes and regolith thickness (Pelletier and Rasmussen, 2009a, b). Rasmussen and Tabor (2007) demonstrated that regolith depth on stable low-gradient slopes increased exponentially with increasing EEMT. Similarly, Pelletier et al. (2013) found that high EEMT values are associated with large above-ground biomass, deeper soils, and longer distance to the valley bottoms across hillslopes in the Santa Catalina Mountains in southern Arizona. More recently, EEMT estimations have been strongly correlated with water transit times, water solute concentrations, and dissolution of silicates on a rhyolitic terrain in northern New Mexico (Zapata-Rios et al., 2015a). In these studies, the main constituents of EEMT ( $E_{\mathrm{ppt}}$ and $E_{\text {bio }}$ ) were quantified as an average value, based on climate records from long-term regional databases as these variables exert first-order controls on photosynthesis and effective precipitation (Rasmussen et al., 2011; Chorover et al., 2011).

It is still uncertain how climate variability influences $\mathrm{CZ}$ structure, function, and the timescales of these changes (Chorover et al., 2011; Brooks et al., 2015). Climate variability might directly influence changes in the transfer of mass and energy to the $\mathrm{CZ}$ as climate has a direct control on both $E_{\text {ppt }}$ and $E_{\text {bio. }}$. In the mountains of the southwestern
United States, a large percentage of annual precipitation falls as snow, which is stored during the winter and released as snowmelt during the spring (Clow, 2010). The water from the winter snowpack constitutes the main source of regional water supplies and the largest component of runoff (Bales et al., 2006; Nayak et al., 2010). The regional snowpack has been documented to be declining in the southwestern US (Mote et al., 2005; Clow, 2010) and alterations to the snowpack are likely to produce changes in vegetation, impact water availability (Bales et al., 2006; Harpold et al., 2012; Trujillo et al., 2012), and influence inputs of EEMT. For instance, significant increasing trends in air temperature and decreasing trends in winter precipitation in the last decades have been documented in the upper Rio Grande region in northern New Mexico (Harpold et al., 2012).

The objective of this study was to evaluate climate variability and its influence on the temporal changes of water partitioning and EEMT at the catchment scale in a semi-arid CZ over the last few decades. This investigation took place in the upper part of the JRB in northern New Mexico, a basin dominated by a forest cover and limited human infrastructure. Micro-climate variability was studied based on daily records from two SNOTEL stations using records from 1984 through 2012. Water availability and EEMT were estimated during the same time period, based on precipitation and temperature from the Parameter-elevation Regressions on Independent Slopes Model (PRISM), empirical daily observations of catchment-scale discharge, and satellite-derived net primary productivity (MODIS).

\section{Methods}

\subsection{Study site}

The Jemez River is a tributary of the upper reach of the Rio Grande and is located between Jemez and the Sierra Nacimiento mountains in northern New Mexico (Fig. 1a). Its headwaters originate within the $360 \mathrm{~km}^{2}$ Valles Caldera National Preserve which contains $30 \%$ of the total basin surface (Fig. 1b). The upper JRB is located at the southern margin of the Rocky Mountain ecoregion between latitudes 35.6 and $36.1^{\circ} \mathrm{N}$ and longitudes -106.3 and $-106.9 \mathrm{~W}$. The basin is characterized by a mean elevation of $2591 \mathrm{~m}$ and a gradient in elevation ranging from 1712 to $3435 \mathrm{~m}$. Based on a $10 \mathrm{~m}$ digital elevation model, the catchment drains $1218 \mathrm{~km}^{2}$ above the US Geological Survey (USGS) gauge "Jemez River near Jemez" (35.66 ${ }^{\circ} \mathrm{N}$ and $106.74^{\circ} \mathrm{W}$; USGS $08324000)$, located at an elevation of $1712 \mathrm{~m}$. The basin has a predominant south aspect and a mean catchment slope of $13.7^{\circ}$. The geology consists of rocks of volcanic origin with predominant andesitic and rhyolitic compositions that overlie tertiary to Paleozoic sediments along the western margin of the Rio Grande rift (Shevenell et al., 1987). Common soil types in the basin include Aridisols, Alfisols, Mollisols, and 
(a)

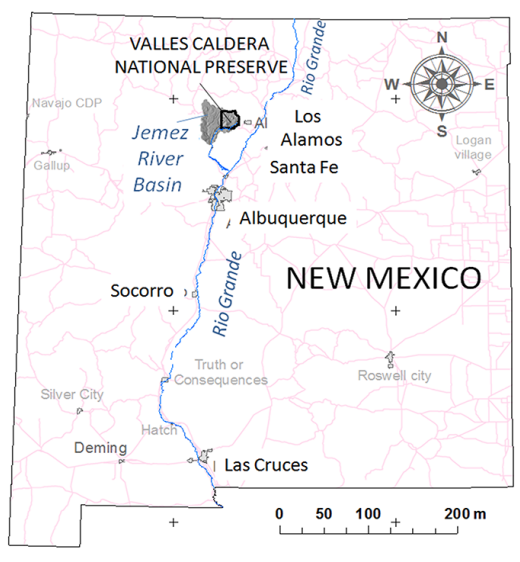

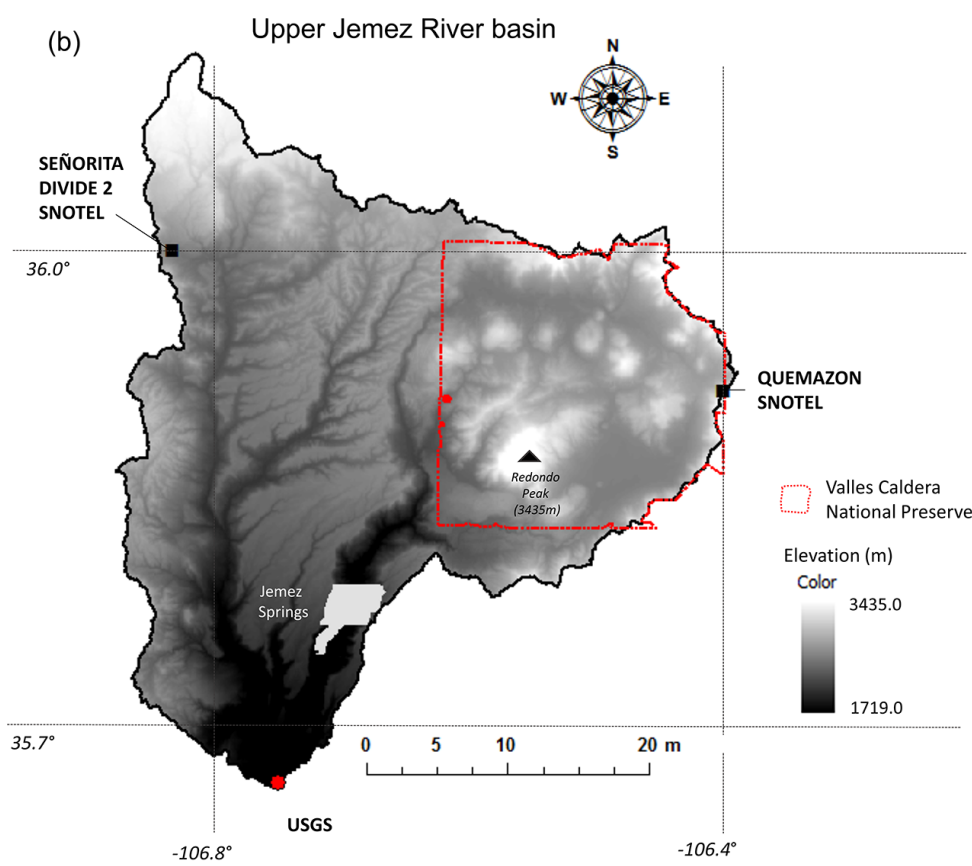

Figure 1. (a) Relative location of study area within the northwestern state of New Mexico, (b) upper JRB, $\sim 1200 \mathrm{~km}^{2}$, delimited above the USGS gauge station “Jemez River near Jemez" (USGS 08324000) based on a $10 \mathrm{~m}$ digital elevation model (DEM).

Inceptisols (Allen et al., 1991, 2002). Precipitation has a bimodal pattern with $50 \%$ of annual precipitation occurring during the winter months (primarily as snow) from October to April and originates from westerly frontal systems. The remaining $50 \%$ of precipitation falls as convectional rainfall during the monsoon season between July and September (Sheppard, 2002). According to the National Land Cover Database (NLCD), the basin is a forested catchment with $79 \%$ under evergreen, deciduous, and mixed forest cover and only $0.5 \%$ of area covered by development and agriculture (http://www.mrlc.gov/nlcd06_leg.php) (Table 1).

\subsection{Climatological stations}

There are two Natural Resources Conservation Service snow telemetry (SNOTEL) stations within the study area with long-term records since 1980 (http://www.wcc.nrcs.usda. gov/snow/; Fig. 1b). The Quemazon station is located at an elevation of $2896 \mathrm{~m}\left(35.92^{\circ} \mathrm{N}\right.$ and $\left.106.39^{\circ} \mathrm{W}\right)$ and the Señorita Divide no. 2 station is located at an elevation of $2622 \mathrm{~m}\left(36.00^{\circ} \mathrm{N}\right.$ and $\left.106.83^{\circ} \mathrm{W}\right)$. The stations collect realtime precipitation, snow water equivalent (SWE), air temperature, soil moisture and temperature, and wind speed and direction. Air temperature records began at the Señorita Divide no. 2 in 1988 and at the Quemazon station in 1989. There are no stations with long-term records for the lower part of the basin.
Table 1. Land use classification of the JRB area. $79.7 \%$ of the total basin is covered by forest, according to the National Land Cover Database (NLCD; http://www.mrlc.gov/nlcd06_leg.php).

\begin{tabular}{lrr}
\hline Land use class & Area $\left(\mathrm{km}^{2}\right)$ & $\%$ \\
\hline Evergreen forest & 847.7 & 69.60 \\
Deciduous forest & 92.6 & 7.61 \\
Mixed forest & 29.8 & 2.44 \\
Grassland/herbaceous & 128.0 & 10.51 \\
Shrub/scrub & 85.0 & 6.98 \\
Pasture/hay & 1.8 & 0.14 \\
Barren land (rock, sand, clay) & 1.3 & 0.10 \\
Developed & 6.1 & 0.50 \\
Cultivated crops & 0.1 & 0.01 \\
Wetlands & 25.2 & 2.07 \\
Open water & 0.4 & 0.03 \\
\hline Total & 1218.0 & 100.00 \\
\hline
\end{tabular}

\subsection{Climate variability}

Climate variability was studied based on 13 variables from the two SNOTEL stations, derived from daily air temperature, precipitation, and maximum SWE, following a similar methodology and data processing procedure as in Harpold et al. (2012). The variables analyzed were winter, summer, and annual air temperature $\left({ }^{\circ} \mathrm{C}\right)$; annual and winter precipitation (mm); maximum SWE (mm); maximum SWE to winter precipitation ratio (-); 1 April SWE (mm); first day snow cover 
(water year day); last day snow cover (water year day); length of snow on the ground (number of days); and SM50, which is the day of the year in which half of the snowpack melts (number of days). Climate records for data analysis were aggregated by water year (from 1 October to 30 September). Winter season was considered to be between October and April and summer season between May and September. The analysis of climate was conducted from 1984 as a starting year to avoid the anomalous wet years recorded at the beginning of 1980 s that were caused by the Pacific Decadal Oscillation (PDO) and El Niño-Southern Oscillation (ENSO) (Harpold et al., 2012; and references therein). The presence of a monotonic increasing or decreasing trend in the 13 climate variables recorded at the two individual stations was evaluated from 1984 through 2012 by applying the nonparametric Mann-Kendall test (MKT) with a $\alpha=0.10$ level of significance and the nonparametric Sen's slope estimator of a linear trend (Yue et al., 2012; Sen, 1968).

\subsection{EEMT estimation}

Energy from both water and net primary productivity are essential on $\mathrm{CZ}$ processes altering soil genesis, mineral dissolution, solute chemistry, and weathering rates (among others) (Birkeland, 1974; Neilson, 2003; Anderson et al., 2007). In this investigation EEMT was calculated as the sum of $E_{\mathrm{ppt}}$ and $E_{\text {bio }}$ (Eq. 1). We applied two different methods to estimate $E_{\mathrm{ppt}}$ and $E_{\text {bio. Following a similar }}$ methodology described in Rasmussen and Gallo (2013), the term EEMT $_{\text {emp }}$ was empirically estimated at the catchment scale based on baseflow estimations and average basin-scale net primary productivity (NPP) derived from MODIS satellite data. In comparison, EEMT model was estimated at the catchment scale based on long-term climate records from PRISM, developed by the climate group at Oregon State University (http://www.wcc.nrcs.usda.gov/ ftpref/support/climate/prism/) and described in Rasmussen et al. (2005, 2011). PRISM is a weighted regression technique that accounts for physiographic factors affecting climate variables, and it has been extensively used in the US (Daly et al., 1994, 2002). The assumption of this study is that the $800 \mathrm{~m}$ PRISM data will provide a reasonable spatial estimation of basin-scale precipitation.

$\mathrm{EEMT}=E_{\mathrm{ppt}}+E_{\mathrm{bio}}\left(\mathrm{Jm}^{-2} \mathrm{~s}^{-1}\right)$

\subsubsection{EEMT $_{\text {emp }}$}

Upper JRB precipitation and air temperature from 1984 through 2012 was obtained using PRISM data at an $800 \mathrm{~m}$ spatial resolution (Daly et al., 1994, 2002). Daily discharge data were available from 1984 through 2012 from the USGS Jemez River near Jemez gauge station (http://waterdata.usgs. gov/nwis). The upper Jemez River has not been subjected to flow regulation, and almost $60 \%$ of the annual discharge occurs during the snowmelt period between March and May.
Daily discharge records were normalized by catchment area, and mean daily discharge was aggregated into water years.

Precipitation $(P)$ on the land surface was partitioned between quickflow $(S)$ and catchment wetting $(W)$. $S$ represents water that directly contributes to streamflow discharge as a response to precipitation events; thus this amount of water is not transferred to the CZ. W is the total amount of water that infiltrates the soil, of which a portion is available for vaporization $(V)$ including vegetation uptake. The remaining portion of $W$ flows though the $\mathrm{CZ}$ and contributes to baseflow $(U) . V$ was estimated at the annual scale as the difference between $P$ and discharge $(Q)$. $Q$ was separated between $S$ and $U$ using a one-parameter low-pass filter (Lyne and Hollick, 1979; Arnold and Allen, 1999; Eckhardt, 2005; Troch et al., 2009) (Eq. 2).

$U_{k}=a U_{k-1}+\frac{1-a}{2}\left(Q_{k}-Q_{k-1}\right)$
$U_{k} \leq Q_{k}$,

where $a$ is a filter parameter set to 0.925 . This filter was passed twice, backward and forward in time, to improve the partitioning of $U$ and $S$ at the beginning of the time series. After this, daily values of $Q, U$, and $S$ were integrated to annual timescales. Alterations in snowmelt timing were evaluated with $Q_{50}$, which indicates the day of the water year when $50 \%$ of the total annual discharge is recorded at the catchment outlet (Clow, 2010; Stewart et al., 2004).

The term $E_{\text {ppt_emp }}$ (energy input through precipitation) was calculated as stated in Eq. (3) based on estimations of $U$ and mean PRISM-derived air temperature at the catchment scale (Rasmussen et al., 2011; Rasmussen and Gallo, 2013).

$E_{\mathrm{ppt}}=U \cdot C_{\mathrm{w}} \cdot \Delta T\left(\mathrm{~J} \mathrm{~m}^{-2} \mathrm{~s}^{-1}\right)$

In Eq. (3), $C_{\mathrm{w}}$ is the specific heat of water $\left(4187 \mathrm{~J} \mathrm{~kg}^{-1} \mathrm{~K}^{-1}\right.$ ) and $\Delta T$ is the difference in temperature between ambient temperature and $0^{\circ} \mathrm{C}$, calculated as $T_{\text {ambient }}-T_{\text {ref }}$ $\left(273.15^{\circ} \mathrm{K}\right)$.

\section{Net primary productivity}

Mean annual NPP at the catchment scale was estimated at a $1 \mathrm{~km}$ spatial resolution for the years 2000-2012 using data MOD17A3 from MODIS (Zhao and Running, 2010) (http: //modis-land.gsfc.nasa.gov/npp.html). $E_{\text {bio }}$ was calculated as indicated in Eq. (4) and presented in Rasmussen et al. (2011) and Rasmussen and Gallo (2013).

$E_{\text {bio }}=\mathrm{NPP} \cdot h_{\text {bio }}\left(\mathrm{Jm}^{-2} \mathrm{~s}^{-1}\right)$,

where $h_{\text {bio }}$ is the specific biomass enthalpy and equivalent to $22 \mathrm{~kJ} \mathrm{~m}^{-2} \mathrm{~s}^{-1}$ (Lieth, 1975; Phillips, 2009). As MODIS data were only available from the year 2000 onwards, single and multivariate linear regression analysis were estimated with the objective of finding a statistical model to extend 
Table 2. Site and meteorological information for the SNOTEL Quemazon and Señorita Divide no. 2 stations located at high elevations in the upper part of the JRB.

\begin{tabular}{|c|c|c|c|c|c|c|c|c|c|c|}
\hline \multirow[b]{2}{*}{$\begin{array}{l}\text { Station } \\
\text { ID }\end{array}$} & \multirow[b]{2}{*}{$\begin{array}{l}\text { Station } \\
\text { name }\end{array}$} & \multirow[b]{2}{*}{$\begin{array}{l}\text { Elevation } \\
\quad(\mathrm{m})\end{array}$} & \multirow[b]{2}{*}{$\begin{array}{l}\text { Latitude } \\
\left({ }^{\circ} \mathrm{N}\right)\end{array}$} & \multirow[b]{2}{*}{$\begin{array}{l}\text { Longitude } \\
\left({ }^{\circ} \mathrm{W}\right)\end{array}$} & \multirow[b]{2}{*}{$\begin{array}{r}\text { Active } \\
\text { since }\end{array}$} & \multicolumn{2}{|c|}{$\begin{array}{c}\text { Mean air } \\
\text { temperature }\left({ }^{\circ} \mathrm{C}\right)\end{array}$} & \multicolumn{2}{|c|}{$\begin{array}{c}\text { Mean } \\
\text { precipitation }(\mathrm{mm})\end{array}$} & \multirow[b]{2}{*}{$\begin{array}{r}\text { Max } \\
\text { SWE (mm) }\end{array}$} \\
\hline & & & & & & Year $^{1}$ & Winter $^{2}$ & Year $^{1}$ & Winter $^{2}$ & \\
\hline 708 & Quemazon & 2896 & 35.92 & -106.39 & 1980 & 3.98 & -0.87 & 700.78 & 347.45 & 242.53 \\
\hline 744 & Senorita Divide no. 2 & 2622 & 36.00 & -106.83 & 1980 & 4.23 & -0.90 & 685.98 & 422.87 & 239.20 \\
\hline
\end{tabular}

Note: The analysis of precipitation since water year (WY) $1984 .{ }^{1}$ Water Year: 1 October-30 September; ${ }^{2}$ Winter: 1 October-31 March. Temperature data availability since 1989 for the Quemazon and 1988 for the Senorita Divide no. 2 station

$E_{\text {bio_emp }}$ records back to 1984 . Using a similar approach as Rasmussen and Tabor (2007), linear regressions were used between $E_{\text {bio_emp }}$ and climate variables from the SNOTEL stations and the entire basin.

\subsection{EEMT $_{\text {model }}$}

$E_{\text {ppt_model }}$ was calculated based on estimations of effective precipitation $\left(P_{\text {eff }}\right)$ which is defined as the amount of water that enters the $\mathrm{CZ}$ in excess of evapotranspiration and is available to flow through the CZ (Rasmussen et al., 2005; Eq. 5).

$E_{\text {ppt_model }(i)}=P_{\text {eff }(i)} \cdot C_{\mathrm{w}} \cdot \Delta T$,

where $P_{\operatorname{eff}(i)}$ is the monthly effective precipitation calculated as the difference between monthly PRISM precipitation and monthly potential evapotranspiration, calculated using the Thornthwaite equation (Rasmussen et al., 2005; Thornthwaite, 1948). $P_{\text {eff }}$, calculated as the difference between monthly precipitation and potential evapotranspiration, has been traditionally used in soil water balances (Arkley, 1963). $C_{\mathrm{w}}$ and $\Delta T$ are the same parameters described in Eq. (3). $E_{\mathrm{ppt}(i)}$ model was calculated on a monthly basis only for the months when precipitation is larger than evapotranspiration $\left(P_{\text {eff }(i)}>0\right)$, and these values were integrated in water years. $E_{\text {bio_model }}$ was estimated as indicated in Eq. (4), and NPP was calculated following an empirical relationship based on air temperature (Eq. 6; Lieth, 1975).

$\mathrm{NPP}(i)=\frac{3000}{1+\mathrm{e}^{1.315-0.119 T_{\mathrm{a}}}} \cdot \frac{\text { days }(i)}{365 \frac{\text { days }}{\text { year }}}$

$\mathrm{NPP}_{(i)}$ is the monthly NPP in $\mathrm{g} \mathrm{m}^{-2} \mathrm{yr}^{-1}$, and $T_{\mathrm{a}}$ is the monthly air temperature. Days $(i)$ over the number of days in a year is an NPP time correction. Similar to Eq. (5), $E_{\text {bio_model }}$ was calculated only for the months where $P_{\operatorname{eff}(i)}>0$. For a detailed description of EEMT, see Rasmussen et al. (2005, 2011, 2015), Rasmussen and Tabor (2007), and Rasmussen and Gallo (2013).

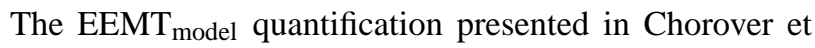
al. (2011) has a relative mean prediction error of $\sim 25 \%$ relative to the predicted value. However, we are using mean trends in EEMT at this catchment-scale study, so we believe that even though the EEMT calculation may have errors, the mean trends presented in this investigation are close to the true values.

\subsection{Water availability, water partitioning, and climate controls on water availability}

A trend analysis was conducted using data from 1984 through 2012 on each component of the water partitioning analysis $\left(P, Q, U, S, V, W, Q_{50}\right)$, and EEMT using the nonparametric MKT and the Sen's slope estimator of a linear trend with a $\alpha=0.10$ level of significance (Yue et al., 2012; Sen, 1968). Relationships between climate, hydrological variables, and EEMT were examined by simple and multiple linear regression analysis with parameters fit through a least-square iterative process (Haan, 1997).

\section{Results}

\subsection{Climate variability}

Records from the Quemazon SNOTEL station from 1984 to 2012 indicated a mean annual precipitation of $701 \mathrm{~mm}$, of which $50 \%$ fell during the winter months with a mean maximum SWE of $242.5 \mathrm{~mm}$. The mean annual and winter temperatures at this site were 3.98 and $-0.87{ }^{\circ} \mathrm{C}$, respectively. During the same time period, Señorita Divide no. 2 station had a mean annual precipitation of $686 \mathrm{~mm}$, of which $61 \%$ fell during the winter, with a mean maximum SWE recorded of $239.2 \mathrm{~mm}$. The mean annual and winter temperatures at the Señorita Divide no. 2 site were 4.23 and $-0.90^{\circ} \mathrm{C}$, respectively (Table 2).

During the 3 decades of analysis, 7 out of the 13 climate variables in both stations showed a statistically significant trend (Table 3). Mean winter, summer, and annual air temperatures at the Quemazon station increased significantly by $1.3^{\circ} \mathrm{C}(p<0.001), 1.0^{\circ} \mathrm{C}(p<0.01)$ and $1.4^{\circ} \mathrm{Cdecade}^{-1}$ $(p<0.001)$, respectively. Similarly, the same variables at the Señorita Divide no. 2 station increased $1.0^{\circ} \mathrm{C}(p<0.05)$, $1.0^{\circ} \mathrm{C}(p<0.01)$, and $1.2^{\circ} \mathrm{C}(p<0.001) \mathrm{decade}^{-1}$, respec- 
Table 3. Climatic time series trends for the Quemazon and Señorita Divide no. 2 SNOTEL stations from 1984-2012. A trend in the precipitation time series was evaluated with the MKT and Sen's slope estimator. Trends were considered statistically significant at $p \leq 0.1$. The results showed an increasing trend in winter, summer, and annual temperature in the two stations. Annual and winter precipitation, maximum SWE, and 1 April SWE decreased in both stations during the 29 years analyzed. The last day of snow cover decreases significantly only at the Quemazon station. No significant trend was observed for the SWE: winter P ratio, duration of snowmelt SM50, and length of snow on the ground.

\begin{tabular}{lrr|rr}
\hline & \multicolumn{2}{c|}{ Quemazon } & Señorita Divide no. 2 \\
\cline { 2 - 5 } Variable & $\begin{array}{r}Q \text { Sen's slope } \\
\text { estimator }\end{array}$ & Sig $^{\text {a }}$ & $\begin{array}{r}Q \text { Sen's slope } \\
\text { estimator }\end{array}$ & Sig $^{\text {a }}$ \\
\hline Winter temp. & 0.13 & $* * * *$ & 0.10 & $* *$ \\
Summer temp. & 0.10 & $* * *$ & 0.10 & $* * *$ \\
Annual temp. & 0.14 & $* * * *$ & 0.12 & $* * * *$ \\
Annual precip. (mm) & -6.98 & $* * *$ & -7.32 & $* *$ \\
Winter precip. (mm) & -4.16 & $*$ & -5.94 & $* *$ \\
Max SWE (mm) & -3.31 & $*$ & -3.47 & $*$ \\
SWE: winter $P$ ratio & -0.005 & & -0.002 & \\
1 April SWE & -6.05 & $* *$ & -5.44 & $*$ \\
Max SWE (day) & -0.57 & $* *$ & -0.33 & \\
SM50 (days) & -0.02 & & 0.12 & \\
First day snow cover (day) & -0.50 & & -0.17 & \\
Last day snow cover (day) & -0.65 & $* *$ & -0.60 & \\
Snow on ground (days) & -0.12 & & &
\end{tabular}

${ }^{\text {a }}$ Statistical significance; ${ }^{*} P<0.1$ ** $^{*} P<0.05$; ** $P<0.01$; **** $P<0.001$.

tively. The rates of increase in winter and annual air temperatures were larger in Quemazon, which was the higher elevation station. Annual precipitation decreased in both stations at similar rates per decade. Quemazon station annual precipitation decreased $69.8 \mathrm{~mm} \mathrm{decade}^{-1}(p \leq 0.01)$ and Señorita Divide no. 2 decreased $73.2 \mathrm{~mm} \mathrm{decade}^{-1}(p \leq$ $0.05)$. Winter precipitation decreased faster at the Señorita Divide no. 2, the lower elevation station $\left(59.4 \mathrm{~mm} \mathrm{decade}^{-1}\right.$; $p \leq 0.05)$ than at the Quemazon station $\left(41.6 \mathrm{~mm} \mathrm{decade}^{-1}\right.$; $p \leq 0.1)$. Maximum SWE decreased in both stations at similar rates, $-34.7 \mathrm{~mm} \mathrm{decade}^{-1}$ at Señorita Divide no. 2 and $-33.1 \mathrm{~mm} \mathrm{decade}^{-1}$ at the Quemazon station $(p \leq$ 0.1 . There was no significant trend in the ratio between SWE to winter precipitation at either station. Observed 1 April SWE also decreased $-60.5 \mathrm{mmdecade}^{-1}(p \leq$ $0.05)$ and $-54.4 \mathrm{~mm} \mathrm{decade}^{-1}(p \leq 0.1)$ at the Quemazon and Señorita Divide no. 2 stations, respectively. The day of occurrence of maximum SWE recorded at the Quemazon station showed a significant trend, indicating that maximum SWE is occurring 5.7 days earlier every decade $(p \leq 0.05)$. However, this same trend was not observed at the Señorita Divide no. 2 station. Variables such as SM50, initiation of snow cover, and snow cover duration did not indicate any trend of change in either station at the $90 \%$ confidence level. In contrast, there is a decreasing trend in the last day of snow cover, which is happening about 6 days sooner per decade in the Quemazon station $(p<0.05)$. Last day of snow cover at the Señorita Divide no. 2 station did not show a significant trend (Table 3).

\section{Water partitioning}

Mean precipitation in the JRB from 1984 to 2012 was $617 \mathrm{~mm}$, with observed extreme values of $845 \mathrm{~mm}$ in 1985 and $336 \mathrm{~mm}$ in 2002. During the analysis period, winter precipitation represented $54 \%$ of total annual precipitation. Mean annual precipitation at the catchment scale correlated significantly with the mean annual precipitation recorded at the Quemazon $\left(R^{2}=0.45 ; p<0.0001\right)$ and Señorita Divide no. 2 stations $\left(R^{2}=0.73 ; p<0.0001\right)$. In this same timeframe average, minimum and maximum basin-scale temperatures were $6.1,-1.5$, and $13.6^{\circ} \mathrm{C}$, respectively. In general, January was the coldest and July was the warmest month. Basin-scale mean annual and winter temperatures indicated a statistically significant increasing trend of 0.5 and $0.4{ }^{\circ} \mathrm{C} \mathrm{decade}^{-1}$ (not shown). Mean annual temperature in the JRB significantly correlated with the mean annual temperature recorded at the Quemazon $\left(R^{2}=0.29 ; p<0.006\right)$ and Señorita Divide no. 2 stations $\left(R^{2}=0.67 ; p<0.0001\right)$ (not shown).

Mean river basin discharge during the study period was $0.15 \mathrm{~mm} \mathrm{day}^{-1}$, and the maximum and minimum historical streamflow discharges were 2.97 and $0.008 \mathrm{~mm} \mathrm{day}^{-1}$, respectively. In the 29 years of daily discharge records, $90 \%$ of the time discharge surpassed $0.03 \mathrm{~mm} \mathrm{day}^{-1}$ and $10 \%$ of the time exceeded $0.38 \mathrm{~mm}$ day $^{-1}$. Peak discharge occurred between March and May and $58 \%$ of the annual discharge flowed between these months. 


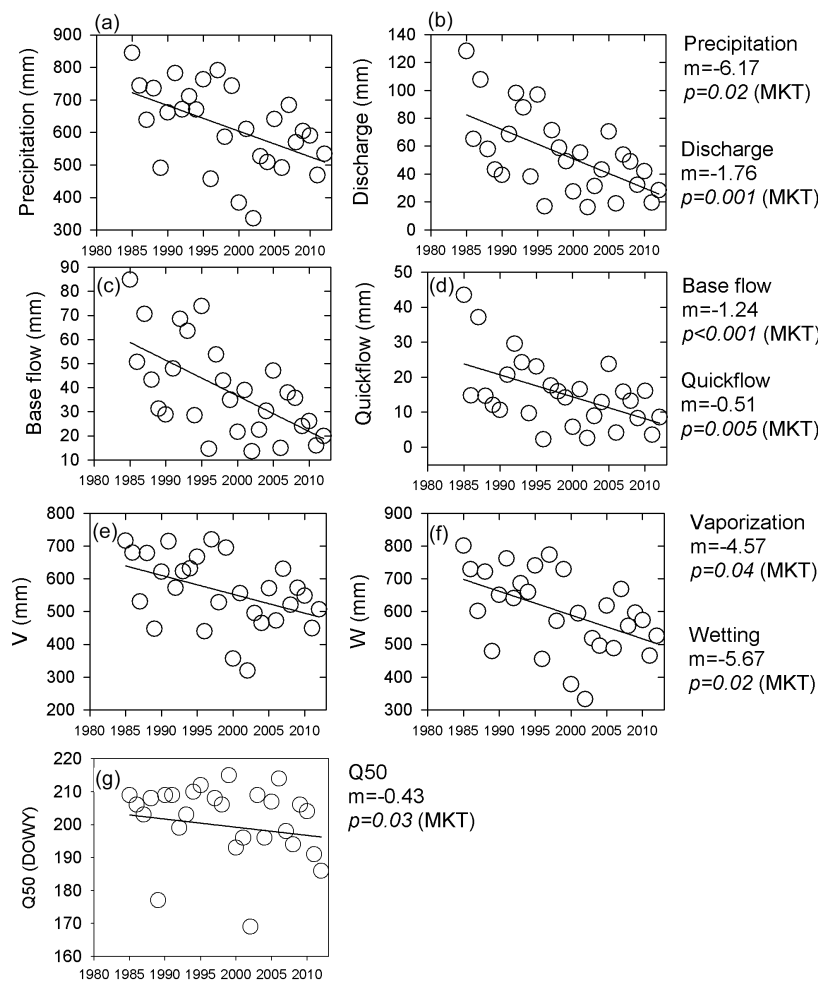

Figure 2. Precipitation and water partitioning at the upper Jemez River catchment scale. There was a significant decreasing trend quantified by the Mann-Kendall test (MKT) in the JRB precipitation and all the components of the water partitioning. For instance, precipitation at the catchment scale decreased during the last 3 decades at a rate of $6.17 \mathrm{~mm}$ per year and discharge at $1.76 \mathrm{~mm} \mathrm{yr}^{-1}$. $Q_{50}$ indicated that discharge is occurring 4.3 days earlier per decade.

From 1984 to $2012,3 \%$ of annual precipitation became quickflow and contributed directly to the streamflow discharge $(3 \% P$; standard deviation $\mathrm{SD}=1.2 \% P$ ). As a result, $97 \%$ of the annual precipitation $(\mathrm{SD}=1.2 \% P)$ infiltrated and was available for vegetation uptake. This $97 \%$ of annual precipitation is further partitioned between vaporization and baseflow. The amount of water vaporized into the atmosphere represented $91 \%$ of the annual precipitation $(\mathrm{SD}=3.4 \% P)$. Baseflow corresponded to $6.1 \%$ of the annual precipitation $(\mathrm{SD}=2.2 \% P)$ and represented the largest component of discharge $(73.2 \% Q ; \mathrm{SD}=5.4 \% Q)$. Quickflow represented the remaining $26.8 \%$ of annual discharge $(\mathrm{SD}=5.4 \% Q)$.

There was a significant decreasing trend in precipitation and all the water partitioning components in the upper JRB, as quantified by the MKT (Fig. 2). Precipitation in the basin decreased at a rate of $-61.7 \mathrm{~mm}$ decade $^{-1}$ $(p=0.02)$ (Fig. 2a), while discharge decreased at a rate of $-17.6 \mathrm{~mm} \mathrm{decade}^{-1}(p=0.001)$ (Fig. 2b). The two components of discharge, baseflow and quickflow, decreased at a rate of $-12.4 \mathrm{~mm}(p<0.001)$ and $-5.1 \mathrm{~mm}$
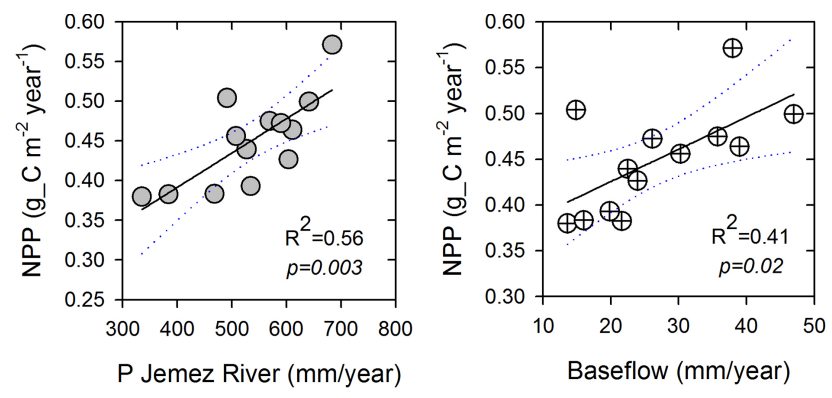

Figure 3. (a) Positive linear correlation between precipitation in the upper JRB and annual NPP in the upper JRB-derived from MODIS; (b) linear correlation between baseflow and annual NPP in the upper JRB. Forest productivity is water limited in the upper JRB. Other variables such as annual, winter, and summer air temperature did not correlate with NPP.

$(p=0.005)$ decade $^{-1}$, respectively (Fig. 2c, d). Water loss by vaporization decreased $-45.7 \mathrm{~mm} \mathrm{decade}^{-1}(p=$ 0.04; Fig. 2e) and wetting decreased $-56.7 \mathrm{~mm} \mathrm{decade}^{-1}$ $(p<0.02$; Fig. 2f). In addition to the decreasing trend in the amount of basin-scale discharge, $Q_{50}$ showed that $50 \%$ of annual discharge is occurring 4.3 days earlier per decade $(p=0.03)$.

\subsection{EEMT}

\subsubsection{EEMT $_{\text {emp }}$}

Using the available 2000-2012 remote-sensing data, mean MODIS NPP was found to be $450 \mathrm{~g} \mathrm{Cm}^{-2}$ $\left(\mathrm{SD}=57.1 \mathrm{~g} \mathrm{C} \mathrm{m}^{-2}\right)$. Using these 13 years of data, no trend in the mean annual NPP for the upper JRB was found. However, mean annual NPP was positively correlated with basin-scale precipitation $\left(R^{2}=0.56 ; p=0.003\right)$ and baseflow $\left(R^{2}=0.41 ; p=0.02\right)$ (Fig. 3). These results indicated that forest productivity in the upper JRB is primarily limited by water availability, since other climate variables recorded at the two SNOTEL stations were not good predictors of NPP. As with any spatial and temporal regression between climate and MODIS data, there are potential errors associated with forest disturbance, interannual lag effects, and interseason variability of water availability and other factors. We also note that the significant relationship, albeit with variability and error, likely captures these effects on this timescale of the study when no large-scale disturbance occurred.

From 1984 through 2012, mean $E_{\mathrm{ppt} \_ \text {emp }}$ was $1.03 \mathrm{MJ} \mathrm{m}^{2} \mathrm{yr}^{-1}\left(\mathrm{SD}=0.49 \mathrm{MJ} \mathrm{m}^{2} \mathrm{yr}^{-1}\right)$ and mean $E_{\text {bio_emp }}$ was $9.89 \mathrm{MJ} \mathrm{m}^{2} \mathrm{yr}^{-1}\left(\mathrm{SD}=1.26 \mathrm{MJ} \mathrm{m}^{2} \mathrm{yr}^{-1}\right)$. Multivariate regression analysis indicated that precipitation at the Quemazon station and the upper JRB were the best predictors of $E_{\text {bio_emp }}\left(R^{2}=0.66 ; p=0.06\right)$. Using this multivariate linear regression model, $E_{\text {bio_emp }}$ data were extrapolated for the years 1984-1999. Using the combined data set 

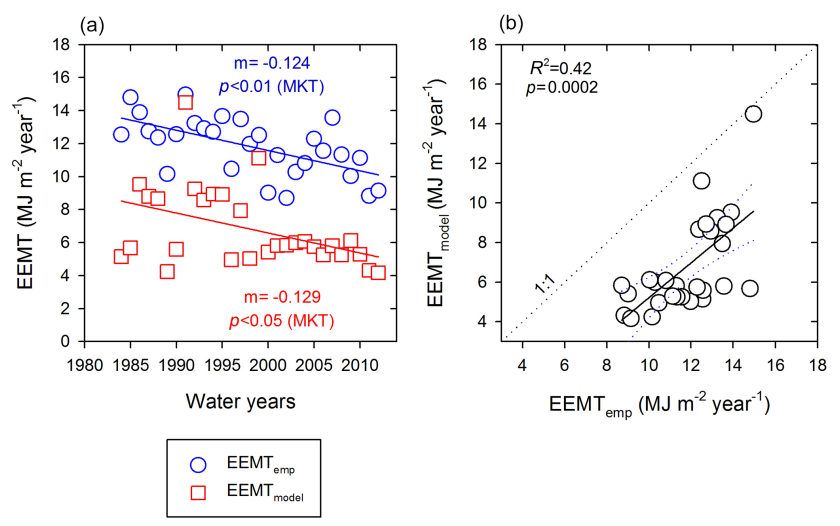

Figure 4. (a) $E_{E M T}$ emp and EEMT $T_{\text {model }}$ showed similar significant decreasing trends from 1984 to 2012 of 1.2 and $1.3 \mathrm{MJ} \mathrm{m}^{-2} \mathrm{yr}^{-1}$; (b) $\mathrm{EEMT}_{\mathrm{emp}}$ and $\mathrm{EEMT}_{\text {model }}$ showed a significant linear correlation.

from extrapolated and measured $E_{\text {bio_emp }}$ the mean annual $E_{\text {bio_emp }}$ was $10.8 \mathrm{MJ} \mathrm{m}^{2} \mathrm{yr}^{-1} \quad\left(\mathrm{SD}=1.37 \mathrm{MJ} \mathrm{m}^{2} \mathrm{yr}^{-1}\right)$ for the period from 1984 to 2012. Mean EEMT $_{\mathrm{emp}}$ was $11.83 \mathrm{MJ} \mathrm{m}^{2} \mathrm{yr}^{-1} \quad\left(\mathrm{SD}=1.74 \mathrm{MJ} \mathrm{m}^{2} \mathrm{yr}^{-1}\right)$ and $E_{\text {bio_emp }}$ represented $92 \%(\mathrm{SD}=0.03 \%)$ of the total $\mathrm{EEMT}_{\mathrm{emp}}$ during the study period.

\subsubsection{EEMT $_{\text {model }}$}

From 1984 through 2012 mean $E_{\text {ppt_model }}$ was $0.1 \mathrm{MJ} \mathrm{m}^{2} \mathrm{yr}^{-1}\left(\mathrm{SD}=0.07 \mathrm{MJ} \mathrm{m}^{2} \mathrm{yr}^{-1}\right)$ and mean $E_{\text {bio_model }}$ was $6.72 \mathrm{MJ} \mathrm{m}^{2} \mathrm{yr}^{-1}\left(\mathrm{SD}=2.33 \mathrm{MJ} \mathrm{m}^{2} \mathrm{yr}^{-1}\right)$. During this

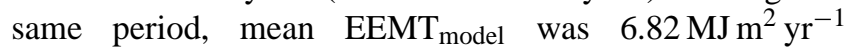
$\left(\mathrm{SD}=2.38 \mathrm{MJ} \mathrm{m}^{2} \mathrm{yr}^{-1}\right)$ and $E_{\text {bio_model }}$ represented $99 \%$ $(\mathrm{SD}=1.2 \%)$ of the total $\mathrm{EEMT}_{\text {model }}$.

EEMT $_{\text {emp }}$ was, on average, 1.7 times larger than EEMT $_{\text {model }}$. Both EEMT $\mathrm{emp}_{\text {and EEMT }}$ model showed a significant linear correlation $\left(R^{2}=0.42 ; p=0.0002\right)$ and a similar decreasing trend of $1.2 \mathrm{MJ} \mathrm{m}^{2}$ decade $^{-1}(p \leq 0.01)$ and $1.3 \mathrm{MJ} \mathrm{m}^{2}$ decade $^{-1}(p \leq 0.05)$, respectively (Fig. 4). Detailed estimations of EEMT emp $_{\text {and }}$ EEMT model $_{\text {and their }}$ components can be found in Table S1 (in the Supplement). Figure 5 highlights changes of EEMT in the upper JRB in relation to water availability from 1984 to 2012. EEMT was positively correlated to annual baseflow, increasing during wet years and decreasing during dry years.

\section{Discussion}

\subsection{Climate variability}

Global climate is changing and the instrumental records in the southwestern US for the last 3 decades indicate a decline in precipitation and increasing air temperatures in the region (Hughes and Diaz, 2008; Folland et al., 2001). Global climate models further predict drier conditions and a more

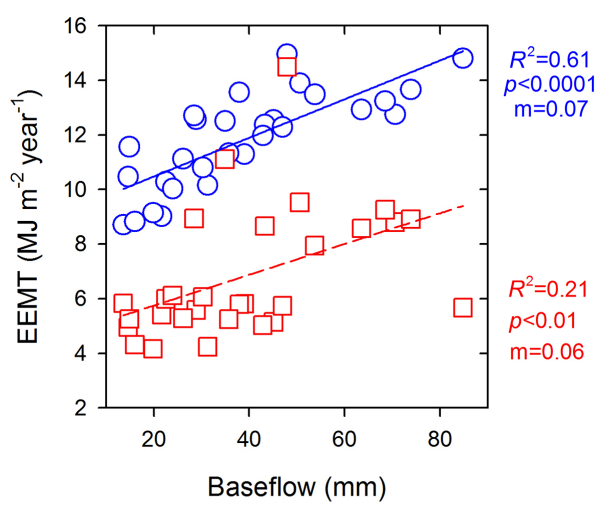

$\begin{array}{ll}\bigcirc & \text { EEMT }_{\text {emp }} \\ \square & \text { EEMT }_{\text {model }}\end{array}$

Figure 5. Relationship between water availability and EEMT. Baseflow and EEMT showed a positive linear correlation. As water availability in the JRB decreases, indicated by baseflow, EEMT also decreases.

arid climate for the 21 st century in this region (Seager et al., 2007). For instance, according to low- and high-emission scenarios, global climate models indicate a substantial increase in air temperature between 0.6 and $2.2^{\circ} \mathrm{C}$ and 1.3 and $5.0^{\circ} \mathrm{C}$ for the period $2021-2050$ and by end of the 21 st century, respectively (Barnett et al., 2004; Cayan et al., 2013). An increase in winter temperature of about $0.6^{\circ} \mathrm{C} \mathrm{decade}^{-1}$ was reported from 1984 to 2012 at a regional level in the upper Rio Grande basin (Harpold et al., 2012). In line with these other studies, we found that mean annual and winter air temperature in the upper JRB have increased 0.5 and $0.4{ }^{\circ} \mathrm{C}$ decade $^{-1}$, respectively.

Changes in climate have been found to be a predominant influence in snowpack decline as opposed to changes in land use, forest canopy, or other factors (Hamlet et al., 2005; Boisvenue and Running, 2006). There are high-confidence predictions that snowpacks will continue to decline in northern New Mexico through the year 2100, and projections of snowpack accumulation for mid-century (2041-2070) show a marked reduction for SWE of about $40 \%$ (Cayan et al., 2013). Harpold et al. (2012) found a decrease in annual precipitation and maximum SWE for the upper Rio Grande basin of -33 and $-40 \mathrm{~mm} \mathrm{decade}^{-1}$, respectively. In this study, a clear decreasing trend in annual, winter precipitation, and maximum SWE was observed in records from 1984 to 2012 in the two high-elevation SNOTEL stations. Records in this study showed approximately twice the rate of decrease in annual precipitation and a smaller decrease in maximum SWE of about $7 \mathrm{~mm} \mathrm{decade}^{-1}$, compared to the regional results from Harpold et al. (2012). Harpold et al. (2012) report that SM50 (-2 days decade $\left.{ }^{-1}\right)$, snow cover length $\left(-4.2\right.$ days decade $\left.{ }^{-1}\right)$, day of maximum SWE (-3.31 days decade $\left.{ }^{-1}\right)$, and last day of snow cover 
$\left(-3.45\right.$ days decade $\left.{ }^{-1}\right)$ for the Rio Grande basin showed statistically significant trends. However, based on our analysis from the individual SNOTEL stations, these variables did not show any statistically significant trends.

\subsection{Changes in discharge and evapotranspiration}

Decreasing trends in discharge ranging from 10 to $30 \%$ are expected during the 21 st century for the western US (Milly et al., 2005), and maximum peak streamflow is expected to happen 1 month earlier by 2050 (Barnett et al., 2005). Furthermore, it has been reported that streamflow in snowmeltdominated river basins is more sensitive to wintertime increases in temperature (Barnett et al., 2005). In this study, we have found that $50.5 \%$ of annual streamflow occurred between (April) and beginning of the summer (June). This result is congruent with other studies in snowmelt-dominated systems in the region (Clow, 2010). Previous research in the southwest has found that the timing of snowmelt is shifting to early times ranging from a few days to weeks (Stewart et al., 2004; Mote et al., 2005; McCabe and Clark, 2005). For instance, Clow (2010) reports that in southern Colorado rivers, there is a trend toward earlier snowmelt that varied from 4.0 to 5.9 days decade $^{-1}$ and 1 April SWE decreased between 51 and $95 \mathrm{~mm}$ per decade. In this study, it was found that snowmelt timing in the upper JRB occurred 4.3 days decade $^{-1}$ earlier and 1 April SWE decreased between 54 and $60 \mathrm{~mm} \mathrm{decade}^{-1}$.

The spatial and temporal variability in total evapotranspiration may exhibit significant variability (Tague and Peng, 2013), and contrasting evapotranspiration trends' directions have been reported in different studies around the world (Barnett et al., 2005). In the JRB, a snow-dominated system, the decrease in vaporization $\left(45 \mathrm{~mm}\right.$ decade $\left.^{-1}\right)$ is likely a result of the mismatch of the timing of energy and water fluxes. While plant water demand remains relatively low, earlier snowmelt may reduce evapotranspiration by reducing plant/atmospherically available water later during the growing season when demand is higher (Barnett et al., 2005). The decrease in vegetation biomass related to water availability, indicated from the MODIS data at this basin, can also significantly contribute to alter transpiration water losses. An increase in forest water-use efficiency (ratio of water loss to carbon gain) with increasing concentrations of carbon dioxide can also contribute as another cause to the decrease of evapotranspiration fluxes (Keenan et al., 2013). Modeling studies conducted over 100 years support our finding that evapotranspiration has been decreasing in the west arid area of the US (Liu et al., 2013). However, evapotranspiration may increase with temperature in some snow-dominated systems if stored soil or groundwater remains available to plants, either locally or at downslope locations (Goulden et al., 2012; Brooks et al., 2015).

\subsection{Forest productivity}

Reduced carbon compounds resulting from primary production are a fundamental energy component of EEMT (Rasmussen et al., 2011). Modeling and empirical studies indicate that mountain forest productivity in the southwest is sensitive to water and energy limitations (Christensen et al., 2008; Tague et al., 2009; Anderson-Teixeira et al., 2011; ZapataRios et al., 2015b; Zapata-Rios, 2015). Trujillo et al. (2012) found that the satellite derived Normalized Difference Vegetation Index (NDVI) greening increased and decreased proportionally to the changes in snowpack accumulation along a gradient in elevation in the Sierra Nevada, while ZapataRios et al. (2015b) and Zapata-Rios (2015) found similar results across a gradient of energy created by aspect differences at higher elevations in the Jemez Mountains. Furthermore, energy limitations to productivity have been observed in colder sites at high elevations (Trujillo et al., 2012; Anderson-Teixeira et al., 2011; Zapata-Rios et al., 2015b; Zapata-Rios, 2015). Since the mid-1980s increases have been documented in wildfires and tree mortality rates in highelevation forests due to an increase in spring and summer temperatures and decrease in water availability (Westerling et al., 2006; Van Mantgem et al., 2009). Results from this study indicated that in the upper JRB, forest productivity was primarily responding to water availability (Fig. 3).

\subsection{EEMT variability}

All of the above results indicate that the JRB is highly susceptible to changes in climate that can affect water availability and ecosystem productivity which impacts EEMT. Rasmussen et al. (2005) estimated low rates of $\mathrm{EEMT}_{\text {model }}<15 \mathrm{MJ} \mathrm{m}^{-2} \mathrm{yr}^{-1}$ for the majority of the continental US and demonstrated that $E_{\text {bio }}$ was the dominant component of EEMT, with contributions above $50 \%$ of total EEMT in soil orders associated with arid and semi-arid regions. Regions dominated by $E_{\text {bio }}$ corresponded to regions facing water limitation and where $E_{\text {bio }}$ accounted for up to $93 \%$ of the total energy and carbon flux to the CZ (Rasmussen et al., 2011; Rasmussen and Gallo, 2013). In semiarid regions vaporization represents over $90 \%$ loss of annual precipitation (Newman et al., 2006), while groundwater recharge accounts for less than $10 \%$ of annual precipitation (Scanlon et al., 2006). Under these conditions, little water remains for $\mathrm{CZ}$ processes in semi-arid regions. Other studies have found that the contributions of $E_{\text {bio }}$ can be 3-7 orders of magnitude larger than other sources of energy influxes to the CZ (Phillips, 2009; Amundson et al., 2007). In this study, we confirmed that for the upper JRB, $E_{\text {bio }}$ was the dominant term from the total EEMT, and $E_{\mathrm{ppt}}$ contributions were small.

A comparison of EEMT $\mathrm{T}_{\text {model }}$ and $\mathrm{EEMT}_{\mathrm{emp}}$ in 86 catchments across the US, characterized by having minimum snow influence, indicated that model and empirical values 
were strongly linearly correlated $\left(R^{2}=0.75 ; p<0.0001\right)$ and $\mathrm{EEMT}_{\text {model }}$ values were larger than $\mathrm{EEMT}_{\mathrm{emp}}$ (Rasmussen and Gallo, 2013). One limitation of the EEMT model method is that it calculates energy during the months when air temperature is above 0 only and assumes no energy associated with precipitation falling as snow. In a snowmeltdominated system like the upper JRB, where snowmelt is the main source of water availability to ecosystems (Bales et al., 2006), EEMT estimations based only on climate data will likely underestimate the energy transfer to the CZ. Therefore, using EEMT emp $_{\text {methodology may }}$ be more suitable for snowmelt-dominated systems. In this study, we found the expected linear correlation between $\mathrm{EEMT}_{\text {model }}$ and $\mathrm{EEMT}_{\mathrm{emp}}\left(R^{2}=0.42 ; p<0.001\right)$; however, $\mathrm{EEMT}_{\text {model }}$ values were smaller than $\mathrm{EEMT}_{\mathrm{emp}}$ values. Although the two methods used in this study to calculate EEMT indicated different absolute values of EEMT, the rates of decrease of EEMT per decade are congruent with each other $\left(\mathrm{EEMT}_{\mathrm{emp}}=1.2 \mathrm{MJ} \mathrm{m}^{2} \mathrm{decade}^{-1} ; \mathrm{EEMT}_{\text {model }}=\right.$ $1.3 \mathrm{MJ} \mathrm{m}^{2}$ decade $^{-1}$ ) (Fig. 5).

While the correlation between EEMT and CZ landscape structure does not necessitate causation, previous work has shown that these correlations are widespread and strong, and thus, EEMT has significant predictive ability (Pelletier and Rasmussen, 2009a, b; Rasmussen and Tabor, 2007; Rasmussen et al., 2005, 2011; Pelletier et al., 2013; ZapataRios et al., 2015a). Although we do not know the exact timescale of CZ change (Brooks et al., 2015), we believe the rates of EEMT change found in the upper JRB between 1.2 and $1.3 \mathrm{MJ} \mathrm{m}^{2}$ decade $^{-1}$ can be significant for $\mathrm{CZ}$ processes. These rates of EEMT change could represent an upward movement of more arid, lower EEMT systems to higher elevations. For instance, in a study conducted in a similar semiarid region in the Santa Catalina Mountains located in southern Arizona, Rasmussen et al. (2015) estimated differences in EEMT of about $25 \mathrm{MJ} \mathrm{m}^{2} \mathrm{yr}^{-1}$ between the upper elevation $(2800 \mathrm{~m})$ covered by mixed conifer forest and low elevation $(800 \mathrm{~m})$ covered by a dry semi-arid desert scrub ecosystem. These changes in EEMT along the $2000 \mathrm{~m}$ elevation gradient in the SCM are equivalent to a difference of $1.25 \mathrm{MJ} \mathrm{m}^{2} \mathrm{yr}^{-1}$ per $100 \mathrm{~m}$ in elevation change. The rates of EEMT change, every $100 \mathrm{~m}$ along the SCM elevation gradient, are similar to observed rates of EEMT change per decade for the entire JRB. Along this elevation gradient contrasting vegetation, soil characteristics, regolith development, chemical depletion, and mineral transformation have been observed between lower and high elevations on similar granitic parent material (Whittaker et al., 1968; Lybrand et al., 2011; Lybrand and Rasmussen, 2014; Holleran et al., 2015). Mollisols and carbon-rich soils have been characterized in convergent areas of higher EEMT versus weakly developed Entisols in lower EEMT landscape positions (Lybrand et al., 2011; Holleran et al., 2015). Furthermore, Rasmussen et al. (2015) determined differences of $3.9 \mathrm{MJ} \mathrm{m}^{2} \mathrm{yr}^{-1}$ between contrasting north- and south-facing slopes at a similar elevation. In areas with similar EEMT, north-facing slopes have soils characterized by greater clay and carbon accumulation (Holleran et al., 2015). According to topographic wetness, differences of $0.9 \mathrm{MJ} \mathrm{m}^{2} \mathrm{yr}^{-1}$ were determined between water-gaining and water-losing portions of the landscape (Rasmussen et al., 2015).

It is still uncertain how the CZ evolves over time and how climate, lithology, and biota influence the function of the $\mathrm{CZ}$ (Chorover et al., 2011). We postulated that a measure of the energy inputs into the $\mathrm{CZ}$ drive $\mathrm{CZ}$ evolution, and their quantification can be related to functions and processes within the CZ. The energy inputs and mass transfer have been integrated in a single and transferable metric (EEMT), quantified as water and carbon fluxes that can be easily transferred and quantified in different ecosystems and regions around the world (Rasmussen and Tabor, 2007; Rasmussen et al., 2011). This allows the comparison of energy inputs to the $\mathrm{CZ}$ in a broad range of sites, climates, and ecosystems. EEMT can be used as a tool to provide an initial identification of landscape locations subjected to higher energy influx (as a result of water and reduced carbon throughputs) or locations where EEMT is changing over time, as it has been indicated in the present study. Consistent changes in EEMT can be indicators of alteration in the function of the $\mathrm{CZ}$, such as weathering process, hydrochemical, and hydrologic response (among others). In regions where temperature, precipitation, water availability, and vegetation are changing, a quantification of EEMT can provide an initial assessment and a metric to evaluate changes in the CZ. The EEMT model has a limitation in that it does not provide information on how energy is distributed within the $\mathrm{CZ}$ and does not provide mechanistic insight into $\mathrm{CZ}$ processes. However, it can be used to identify research sites for further instrumentation and measuring of $\mathrm{CZ}$ processes. Although the quantification of EEMT using the methodologies applied in this study is suitable for large spatial scales, it is limited in that it does not take into account small-scale variabilities induced by topography in solar energy, effective precipitation, NPP, and redistribution of water by differences in microtopography. Therefore, EEMT estimations at small scales (pedon to hillslopes) need to follow a different approach, as indicated in Rasmussen et al. (2015).

\section{Summary}

We investigated how changes in climate in the southwest affect the trends in water availability, vegetation productivity, and the annual influxes of EEMT to the CZ. This investigation took place in the $1200 \mathrm{~km}^{2}$ upper JRB, a semi-arid basin in northern New Mexico, using records from 1984 to 2012. Results at the two SNOTEL stations indicated clear increasing trends in temperature and decreasing trends in precipitation and maximum SWE. Temperature changes include warmer winters $\left(+1.0-1.3^{\circ} \mathrm{C}\right.$ decade $\left.^{-1}\right)$, and generally warmer year-round temperatures $\left(+1.2-1.4^{\circ} \mathrm{C} \mathrm{decade}^{-1}\right)$. 
Precipitation changes include a decreasing trend in precipitation during the winter $\left(-41.6-51.4 \mathrm{~mm} \mathrm{decade}^{-1}\right)$, during the year $\left(-69.8-73.2 \mathrm{~mm} \mathrm{decade}^{-1}\right)$, and maximum SWE $\left(-33.1-34.7 \mathrm{~mm} \mathrm{decade}^{-1}\right)$. At the upper JRB, all the water-partitioning components showed statistical significant decreasing trends including precipitation $\left(-61.7 \mathrm{~mm} \mathrm{decade}^{-1}\right)$, discharge $\left(-17.6 \mathrm{~mm} \mathrm{decade}^{-1}\right)$, and vaporization $\left(-45.7 \mathrm{~mm} \mathrm{decade}^{-1}\right)$. Similarly, $Q_{50}$, an indicator of snowmelt timing, is occurring -4.3 days decade ${ }^{-1}$ earlier. Basin-scale precipitation $\left(R^{2}=0.56 ; p=0.003\right)$ and baseflow $\left(R^{2}=0.41 ; p=0.02\right)$ were the strongest controls on NPP variability, indicating that forest productivity in the upper JRB is water limited. This study showed a positive correlation between water availability and EEMT. For every $10 \mathrm{~mm}$ of change in baseflow, EEMT varies proportionally in $0.6-0.7 \mathrm{MJ} \mathrm{m}^{-2} \mathrm{yr}^{-1}$. From 1984 to 2012, changes in climate, water availability, and NPP have influenced EEMT in the upper JRB. A decreasing trend in EEMT of $1.2-1.3 \mathrm{MJ} \mathrm{m}^{-2}$ decade $^{-1}$ was calculated in this same time frame. Although we cannot determine the timescales of change, these results suggest an upward migration of CZ/ecosystem structure on the order of $100 \mathrm{~m} \mathrm{decade}^{-1}$, and that decadal-scale differences in EEMT are similar to the differences between convergent/hydrologically subsidized and planar/divergent landscapes, which have been shown to be very different in vegetation and $\mathrm{CZ}$ structure. As the landscape moves towards a drier and hotter climate, changes in EEMT of this magnitude are likely to influence $\mathrm{CZ}$ processes.

Author contributions. All authors contributed extensively to this research. All authors discussed the methodology, results, and commented on the manuscript at all stages. Xavier Zapata-Rios analyzed data and prepared the manuscript with contributions from all co-authors.

Acknowledgements. We thank the funding provided by the NSFsupported Jemez River basin and Santa Catalina Mountains Critical Zone Observatory EAR-0724958 and EAR-1331408).

Edited by: P. Saco

\section{References}

Allen, C., Savage, M., Falk, D., Suckling, K., Swetnam, T., Schulke, T., Stacey, P., Morgan, P., Hoffman, M., and Klingel, J.: Ecological restoration of Southwestern ponderosa pine ecosystems: a broad perspective, Ecol. Appl., 12, 1418-1433, 2002.

Allen, R., Peet, R., and Baker, W.: Gradient analysis of latitudinal variation in Southern Rocky-Mountain Forests, J. Biogeogr., 18, 123-139, 1991.

Amundson, R., Richter, D. D., Humphreys, G. S., Jobbagy, E. G., and Gaillardet, J.: Coupling between biota and earth materials in the critical zone, Elements, 3, 327-332, 2007.

Anderson, S. P., von Blanckenburg, F., and White, A. F.: Physical and chemical controls on the critical zone, Elements, 3, 315-319, 2007.

Anderson-Teixeira, K. J., Delong, J. P., Fox, A. M., Brese, D. A., and Litvak, M. E.: Differential responses of production and respiration to temperature and moisture drive the carbon balance across a climatic gradient in New Mexico, Glob. Change Biol., 17, 410-424, 2011.

Arkley, R. J.: Calculation of carbonate and water movement in soil from climate data, Soil Sci., 96, 239-248, 1963.

Arnold, J. and Allen, P.: Automated methods for estimating baseflow and ground water recharge from streamflow records, J. Am. Water Resour. As., 35, 411-424, 1999.

Bales, R. C., Molotch, N. P., Painter, T. H., Dettinger, M. D., Rice, R., and Dozier, J.: Mountain hydrology of the western United States, Water Resour. Res., 42, W08432, 2006.

Barnett, T., Malone, R., Pennell, W., Stammer, D., Semtner, B., and Washington, W.: The effects of climate change on water resources in the west: introduction and overview, Climatic Change, 62, 1-11, 2004.

Barnett, T., Adam, J., and Lettenmaier, D.: Potential impacts of a warming climate on water availability in snow-dominated regions, Nature, 438, 303-309, 2005.

Betts, R. A., Boucher, O., Collins, M., Cox, P. M., Falloon, P. D., Gedney, N., Hemming, D. L., Huntingford, C., Jones, C. D., Sexton, D. M. H., and Webb, M. J.: Projected increase in continental runoff due to plant responses to increasing carbon dioxide, $\mathrm{Na}$ ture, 448, 1037, 2007.

Birkeland, P. W.: Pedology, weathering and geomorphological research, Oxford University Press, London, 1974.

Boisvenue, C. and Running, S.: Impacts of climate change on natural forest productivity - evidence since the middle of the 20th century, Glob. Change Biol., 12, 862-882, 2006.

Brantley, S. L., Goldhaber, M. B., and Ragnarsdottir, K. V.: Crossing disciplines and scales to understand the Critical Zone, Elements, 3, 307-314, 2007.

Brooks, P. D., Troch, P. A., Durcik, M., Gallo, E., and Schlegel, M. Quantifying regional scale ecosystem response to changes in precipitation: not all rain is created equal, Water Resour. Res., 47, W00J08, doi:10.1029/2010WR009762, 2011.

Cayan, D., Tyree, M., Kunkel, K. E., Castro, C., Gershunov, A., Barsugli, J., Ray, A. J., Overpeck, J., Anderson, M., Russell, J., Rajagopalan, B., Rangwala, I., and Duffy, P.: Future Climate: Projected Average, in: Assessment of Climate Change in the Southwest United States: A Report Prepared for the National Climate Assessment, edited by: Garfin, G., Jardine, A., Merideth, R., Black, M., and LeRoy, S., Island Press, Washington, DC, 101$125,2013$. 
Chorover, J., Troch, P. A., Rasmussen, C., Brooks, P. D., Pelletier, J. D., Breshears, D. D., Huxman, T. E., Kurc, S. A., Lohse, K. A., McIntosh, J. C., Meixner, T., Schaap, M. G., Litvak, M. E., Perdrial, J., Harpold, A., and Durcik, M.: How water, carbon, and energy drive critical zone evolution: the Jemez-Santa Catalina critical zone observatory, Vadose Zone J., 10, 884-899, 2011.

Christensen, L., Tague, C. L., and Baron, J. S.: Spatial patterns of simulated transpiration response to climate variability in a snow dominated mountain ecosystem, Hydrol. Process., 22, 35763588, 2008.

Clow, D. W.: Changes in the timing of snowmelt and streamflow in Colorado: a response to recent warming, J. Climate, 23, 22932306, 2010.

Daly, C., Neilson, R. P., and Phillips, D. L.: A statisticaltopographic model for mapping climatological precipitation over mountainous terrain, J. Appl. Meteorol., 33, 140-158, 1994.

Daly, C., Gibson, W., Taylor, G., Johnson, G., and Pasteris, P.: A knowledge-based approach to the statistical mapping of climate, Clim. Res., 22, 99-113, 2002.

Eckhardt, K.: How to construct recursive digital filters for baseflow separation, Hydrol. Process., 19, 507-515, 2005.

Folland, C. K., Karl, T. R., Christy, J. R., Clarke, R. A., Gruza, G. V., Jouzel, J., Mann, M. E., Oerlemans, J., Salinger, M. J. and Wange, S. W.: Observe climate variability and change, in: Climate Change 2001: the Scientific Basis, Contribution of working group I to the third Assessment Report of the Intergovernmental Panel on Climate Change, edited by: Houghton, J. T., Ding, Y., Griggs, D. J., Noguer, M., van der Linden, P. J., Dai, X., Maskell, K., and Johnson, C. A., Cambridge University Press, Cambridge, UK, 99-181, 2001.

Goulden, M. L., Anderson, R. G., Bales, R. C., Kelly, A. E., Meadows, M., and Winston, G. C.: Evapotranspiration along an elevation gradient in California's Sierra Nevada, J. Geophys. Res., 117, G03028, doi:10.1029/2012JG002027, 2012.

Haan, C. T.: Statistical Methods in Hydrology, The Iowa State University Press, Ames, Iowa, 378 pp., 1977.

Hamlet, A., Mote, P., Clark, M., and Lettenmaier, D.: Effects of temperature and precipitation variability on snowpack trends in the western United States, J. Climate, 18, 4545-4561, 2005.

Harpold, A., Brooks, P., Rajagopal, S., Heidbuchel, I., Jardine, A., and Stielstra, C.: Changes in snowpack accumulation and ablation in the intermountain west, Water Resour. Res., 48, W11501, doi:10.1029/2012WR011949, 2012.

Holleran, M., Levi, M., and Rasmussen, C.: Quantifying soil and critical zone variability in a forested catchment through digital soil mapping, Soil, 1, 47-64, doi:10.5194/soil-1-47-2015, 2015.

Hughes, M. K. and Diaz, H. F.: Climate variability and change in the drylands of Western North America, Global Planet. Change, 64, 111-118, 2008.

Keenan, T. F., Hollinger, D. Y., Bohrer, G. B., Dragoni, D., Munger, J. W., Schmid, H. P., and Richardson, A. D.: Increase in forest water-use efficiency as atmospheric carbon dioxide concentrations rise, Nature, 499, 324-327, 2013.

Lieth, H.: Modeling the primary productivity of the world, in: Primary Productivity of the Biosphere, edited by: Lieth, $H$. and Whittaker, R. H., Springer-Verlag, New York, 237-263, 1975.

Liu, M., Tian, H., Yang, Q., Yang, J., Song, X., Lohrenz, S. E., and Cai, W. J.: Long-term trends in evapotranspiration and runoff over the drainage basins of the Gulf of Mexico during 19012008, Water Resour. Res., 49, 1988-2012, 2013.

Lybrand, R. A. and C. Rasmussen.: Linking soil element-masstransfer to microscale mineral weathering across a semiarid environmental gradient, Chem. Geol., 381, 26-39, 2014.

Lybrand, R. A., Rasmussen, C., Jardine, A., Troch, P. A., and Chorover, J.: The effects of climate and landscape position on chemical denudation and mineral transformation in the Santa Catalina mountain critical zone observatory, Appl. Geochem., 26, S80-S84, 2011.

Lyne, V. and Hollick, M.: Stochastic time-variable rainfall-runoff modelling, in: Hydrol. And Water Resources. Syp., publ. 79/10, Inst. Eng. Austr. Natl. Conf., Perth, Australia, 89-92, 1979.

McCabe, G. and Clark, M.: Trends and variability in snowmelt runoff in the western United States, J. Hydrometeorol., 6, 476482, 2005.

Milly, P., Dunne, K., and Vecchia, A.: Global pattern of trends in streamflow and water availability in a changing climate, Nature, 438, 347-350, 2005.

Mote, P., Hamlet, A., Clark, M., and Lettenmaier, D.: Declining mountain snowpack in western north America, B. Am. Meteorol. Soc., 86, doi:10.1175/BAMS-86-1-39, 2005.

Nayak, A., Marks, D., Chandler, D. G., and Seyfried, M.: Long-term snow, climate, and streamflow trends at the Reynolds Creek Experimental Watershed, Owyhee Mountains, Idaho, United States, Water Resour. Res., 46, W06519, doi:10.1029/2008WR007525, 2010.

Neilson, R. P.: The importance of precipitation seasonality in controlling vegetation distribution, in: Changing precipitation regimes and terrestrial ecosystems - A North American Perspective, edited by: Weltzin, J. F. and McPerson, G. R., University of Arizona Press, Tucson, 47-71, 2003.

Newman, B. D., Wilcox, B. P., Archer, S. R., Breshears, D. D., Dahm, C. N., Duffy, C. J., McDowell, N. G., Phillips, F. M., Scanlon, B. R., and Vivoni, E. R.: Ecohydrology of waterlimited environments: a scientific vision, Water Resour. Res., 42, W06302, doi:10.1029/2005WR004141, 2006.

Ohmura, A. and Wild, M.: Is the hydrological cycle accelerating?, Science, 298, 1345-1346, 2002.

Pelletier, J. D. and Rasmussen, C.: Geomorphically based predictive mapping of soil thickness in upland watersheds, Water Resour. Res., 45, W09417, doi:10.1029/2008WR007319, 2009a.

Pelletier, J. D. and Rasmussen, C.: Quantifying the climatic and tectonic controls on hillslope steepness and erosion rate, Lithosphere, 1, 73-80, 2009 b.

Pelletier, J. D., Barron-Gafford, G. A., Breshears, D. D., Brooks, P. D., Chorover, J., Durcik, M., Harman, C. J., Huxman, T. E., Lohse, K. A., Lybrand, R., Meixner, T., McIntosh, J. C., Papuga, S. A., Rasmussen, C., Schaap, M., Swetnam, T. L., and Troch, P. A.: Coevolution of nonlinear trends in vegetation, soils, and topography with elevation and slope aspect: a case study in the sky islands of southern Arizona, J. Geophys. Res.-Earth, 118, 741-758, 2013.

Phillips, J. D.: Biological energy in landscape evolution, Am. J. Sci., 309, 271-289, 2009.

Rasmussen, C.: Thermodynamic constraints on effective energy and mass transfer and catchment function, Hydrol. Earth Syst. Sci., 16, 725-739, doi:10.5194/hess-16-725-2012, 2012. 
Rasmussen, C. and Gallo, E. L.: Technical Note: A comparison of model and empirical measures of catchment-scale effective energy and mass transfer, Hydrol. Earth Syst. Sci., 17, 3389-3395, doi:10.5194/hess-17-3389-2013, 2013.

Rasmussen, C. and Tabor, N. J.: Applying a quantitative pedogenic energy model across a range of environmental gradients, Soil Sci. Soc. Am. J., 71, 1719-1729, 2007.

Rasmussen, C., Southard, R., and Horwath, W.: Modeling energy inputs to predict pedogenic environments using regional environmental databases, Soil Sci. Soc. Am. J., 69, 1266-1274, 2005.

Rasmussen, C., Troch, P. A., Chorover, J., Brooks, P., Pelletier, J., and Huxman, T. E.: An open system framework for integrating critical zone structure and function, Biogeochemistry, 102, 1529, 2011.

Rasmussen, C., Pelletier, J. D., Troch, P. A., Swetnam, T. L., and Chorover, J..: Quantifying topographic and vegetation effects on the transfer of energy and mass to the critical zone, Vadose Zone J., doi:10.2136/vzj2014.07.0102, 2015.

Scanlon, B. R., Keese, K. E., Flint, A. L., Flint, L. E., Gaye, C. B., Edmunds, W. M., and Simmers, I.: Global synthesis of groundwater recharge in semiarid and arid regions, Hydrol. Process., 20, 3335-3370, 2006.

Seager, R., Ting, M., Held, I., Kushnir, Y., Lu, J., Vecchi, G., Huang, H., Harnik, N., Leetmaa, A., Lau, N., Li, C., Velez, J., and Naik, N.: Model projections of an imminent transition to a more arid climate in southwestern North America, Science, 316, 11811184, 2007.

Sen, P. K.: Estimates of the regression coefficient based on Kendall's tau, J. Am. Stat. Assoc., 63, 1379-1389, 1968.

Sheppard, P., Comrie, A., Packin, G., Angersbach, K., and Hughes, M.: The climate of the US Southwest, Clim. Res., 21, 219-238, 2002.

Shevenell, L., Goff, F., Vuataz, F., Trujillo, P. E., Counce, D., Janik, C. and Evans, W.: Hydrogeochemical data for thermal and nonthermal waters and gases of the Valles Caldera - Southern Jemez Mountains Region, New Mexico, Technical report, Los Alamos National Lab, Los Alamos, New Mexico, N M.LA10923-OBES, 1987.

Smil, V.: General energetics: energy in the biosphere and civilization, Wiley Interscience, New York, 1991.

Steffen, W., Crutzen, P. J., and McNeill, J. R.: The anthropocene: are humans now overwhelming the great forces of nature, Ambio, 36, 614-621, 2007.

Stewart, I., Cayan, D., and Dettinger, M.: Changes in snowmelt runoff timing in western North America under a "business as usual" climate change scenario, Climatic Change, 62, 217-232, 2004.

Tague, C. and Peng, H.: The sensitivity of forest water use to the timing of precipitation and snowmelt recharge in the California Sierra: Implications for a warming climate, J. Geophys. Res., $118,875-887,2013$.
Tague, C., Heyn, K., and Christensen, L.: Topographic controls on spatial patterns of conifer transpiration and net primary productivity under climate warming in mountain ecosystems, Ecohydrology, 2, 541-554, 2009.

Thornthwaite, C. W.: An approach toward a rational classification of climate, Geogr. Rev., 38, 55-94, 1948.

Troch, P. A., Martinez, G. F., Pauwels, V. R. N., Durcik, M., Sivapalan, M., Harman, C., Brooks, P. D., Gupta, H., and Huxman, T. Climate and vegetation water use efficiency at catchment scales, Hydrol. Process., 23, 2409-2414, 2009.

Trujillo, E., Molotch, N. P., Goulden, M. L., Kelly, A. E., and Bales, R. C.: Elevation-dependent influence of snow accumulation on forest greening, Nat. Geosci., 5, 705-709, 2012.

van Mantgem, P. J., Stephenson, N. L., Byrne, J. C., Daniels, L. D., Franklin, J. F., Fule, P. Z., Harmon, M. E., Larson, A. J., Smith, J. M., Taylor, A. H., and Veblen, T. T.: Widespread increase of tree mortality rates in the western united states, Science, 323, 521-524, 2009.

Voepel, H., Ruddell, B., Schumer, R., Troch, P. A., Brooks, P. D., Neal, A., Durcik, M., and Sivapalan, M.: Quantifying the role of climate and landscape characteristics on hydrologic partitioning and vegetation response, Water Resour. Res., 47, W00J09, doi:10.1029/2010WR009944, 2011.

Westerling, A. L., Hidalgo, H. G., Cayan, D. R., and Swetnam, T. W.: Warming and earlier spring increase western US forest wildfire activity, Science, 313, 940-943, 2006.

Whittaker, R. H., Buol, S. W., Niering, W. A., and Havens, Y. H.: A soil and vegetation pattern in the Santa Catalina Mountains, Arizona, Soil Science, 105, 440-450, 1968.

Yue, S., Pilon, P., and Cavadias, G.: Power of the Mann-Kendall and Spearman's rho tests for detecting monotonic trends in hydrological series, J. Hydrol., 259, 254-271, 2002.

Zapata-Rios, X.: The influence of climate and landscape on hydrological processes, vegetation dynamics, biogeochemistry and the transfer of effective energy and mass to the critical zone, $\mathrm{PhD}$ Dissertation, Univ. of Ariz., Tucson, Arizona., 192 pp., 2015.

Zapata-Rios, X., McIntosh, J. Rademacher, L., Troch, P. A., Brooks, P. D., Rasmussen, C., and Chorover J.: Climatic and landscape controls on water transit times and silicate mineral weathering in the critical zone, Water Resour. Res., 51, doi:10.1002/2015WR017018, 2015a.

Zapata-Rios, X., Troch, P. A., Brooks, P. D., and McIntosh, J.: Influence of terrain aspect on water partitioning, vegetation structure, and vegetation greening in high elevation catchments in northern New Mexico, Ecohydrology, doi:10.1002/eco.1674, 2015b.

Zhao, M. and Running, S. W.: Drought-induced reduction in global terrestrial net primary production from 2000 through 2009, Science, 329, 940-943, 2010. 